\title{
Evaluasi Nutrisi Pelepah Daun Kelapa Sawit dengan Beberapa Teknik Pengolahan sebagai Pakan Ternak Rumiansia
}

(Nutritional Evaluation of Palm Oil Fronds (POF) with Several Processing Techniques as Ruminant Feed)

\author{
Novia Ulfa Prakasa, Yunasri Usman ${ }^{1}$, Sitti Wajizah* \\ ${ }^{1}$ Program Studi Peternakan, Fakultas Pertanian, Universitas Syiah Kuala \\ *Corresponding Author: sittiwajizah@unsyiah.ac.id
}

\begin{abstract}
Abstrak. Pelepah dan daun kelapa sawit (PDKS) merupakan salah satu hasil samping dari perkebunan kelapa sawit, yang berpotensi sebagai bahan pakan bagi ternak ruminansia. Namun demikian, kualitas nutrisi dan kecernaannya yang rendah merupakan faktor pembatas pemanfaatan PDKS sebagai pakan ternak ruminansia. Berbagai teknologi diperlukan untuk meningkatkan kualitas nutrisi PDKS, salah satunya menggunakan teknologi amoniasi dan fermentasi dengan bantuan mikroorganisme Trichoderma viride. Hasil penelitian menunjukkan bahwa, berbagai teknik pengolahan terhadap PDKS pada penelitian ini berpengaruh sangat nyata $(\mathrm{P}<0,01)$ terhadap kadar bahan kering, protein kasar, lemak kasar, serta BETN, namun tidak berpengaruh nyata $(\mathrm{P}>0,05)$ terhadap kadar serat kasar dan abu. Berdasarkan hasil penelitian dapat disimpulkan bahwa perlakuan fermentasi memberikan hasil yang relatif baik, karena dapat mempertahankan kadar bahan kering dan BETN tetap tinggi, serta cenderung meningkatkan kadar protein substrat dibandingkan perlakuan kontrol.
\end{abstract}

Kata kunci : Amoniasi, fermentasi, kualitas nutrisi, pelepah daun kelapa sawit, Trichoderma viride

Abstract. Oil palm fronds (POF) are one of the by-products of oil palm plantations, which are potential as ruminant feed. However, its low nutritional quality and digestibility are limiting factors for the use of POF as ruminant feed. Various technologies are needed to improve the nutritional quality of POF, such as the use of ammonia and fermentation technology, involving Trichoderma viride as inoculant.The results showed that various processing techniques for POF in this study had a very significant effect $(\mathrm{P}<0.01)$ on dry matter, crude protein, crude fat, and BETN contents, but had no significant effect $(\mathrm{P}>0.05)$ on crude fiber and ash contents. It can be concluded that the fermentation treatment gave relatively good results, because it could maintain high levels of dry matter and BETN, and tended to increase the protein content of the substrate compared to the control treatment.

Keywords: Ammonia, fermentation, nutritional quality, Palm Oil Fronds, Trichoderma viride.

\section{PENDAHULUAN}

Kecenderungan penggunaan lahan untuk penanaman tanaman komoditas pangan, sebagai wilayah perumahan, dan pembangunan industri mengakibatkan semakin kecilnya lahan yang dapat digunakan untuk penanaman hijauan pakan ternak. Oleh karena itu, untuk menjamin ketersedian bahan pakan secara berkesinambungan, pemanfaatan limbah pertanian dan perkebunan sebagai pakan alternatif yang perlu diupayakan. Pemeliharaan ternak ruminansia secara terpadu dapat meningkatkan perkembangan agribisnis bagi para peternak baik dalam sistem produksi terpadu dengan pola pertanian dan perkebunan melalui pemanfaatan limbah yang ramah lingkungan atau dikenal dengan istilah "zero waste production system" (Wahyono et al., 2003).

Perkebunan kelapa sawit menghasilkan beberapa jenis limbah yang dapat dimanfaatkan sebagai pakan ternak, yaitu pelepah, daun, lumpur sawit (solid), dan bungkil inti sawit (BIS). Salah satu cara untuk mengoptimalkan penggunaan serat sawit sebagai bahan pakan ternak dapat dilakukan melalui pengolahan amoniasi dengan urea. Tujuan dari proses amoniasi yaitu untuk meningkatkan daya cernadan meningkatkan kadar nitrogen (N). Selain teknologi amoniasi, ternologi fermentasi juga bertujuan untuk mengubah struktur bahan fisik pakan, pengawetan dan meningkatkan kandungan nutrisi bahan. Pengubahan struktur fisik pada bahan kasar dilakukan oleh enzim lignase sekaligus memperkaya jaringan pakan dengan protein 
mikroorganisme (Sarwono, 1996). Gabungan kedua teknologi amoniasi dan fermentasi merupakan suatu cara untuk meningkatkan kualitas bahan pakan berserat kasar tinggi, karena teknologi amoniasi yang memutus ikatan antara selulosa dan lignin, serta melonggarkan ikatan serat kasar akan memudahkan penetrasi enzim selulase dari mikroba selulolitik untuk mendegradasi bahan pakan berserat pada proses fermentasi, sehingga dapat menurunkan kadar serat kasar dan meningkatkan kecernaan (Hastuti et al., 2011).

Penelitian ini bertujuan untuk mengevaluasi kandungan nutrisi pelepah daun kelapa sawit yang diamoniasi, difermentasi dengan menggunakan Trichoderma viride atau gabungan keduanya (amoniasi, fermentasi/ amofer) sebagai pakan ternak ruminansia.

\section{METODE PENELITIAN}

Penelitian ini dilaksanakan di Laboratorium Nutrisi dan Teknologi Pakan Ternak, Jurusan Peternakan, Fakultas Pertanian, Universitas Syiah Kuala. Banda Aceh.

\section{MATERI DAN METODE}

\section{Materi Penelitian}

Pelepah daun kelapa sawit diperoleh dari perkebunan kelapa sawit warga di Desa Ligan, Kec. Sampoiniet, Kab. Aceh Jaya. Trichoderma viride diperoleh dari Laboratorium Ilmu dan Penyakit Tanaman, Universitas Gadjah Mada, Yogyakarta.

\section{Metode Penelitian}

Penelitian ini merupakan metode eksperimen, dan rancangan yang digunakan adalah rancangan acak lengkap (RAL) yang terdiri atas 4 perlakuan dan 4 ulangan, sehingga diperoleh 16 unit percobaan. Perlakuan terdiri atas P0 (kontrol/PDKS tanpa amoniasi dan fermentasi), P1 (PDKS amoniasi), P2 (PDKS fermentasi), dan P3 (PDKS amoniasi dan fermentasi/ amofer). Masing-masing perlakuan dilakukan selama 3 minggu.

Untuk amoniasi PDKS menggunakan urea dan fermentasi PDKS menggunakan Trichoderma viride dilakukan masing-masing selama 21 hari, sedangkan untuk perlakuan amofer dilakukan 2 tahap, yaitu amoniasi selama 7 hari diikuti dengan fermentasi selama 14 hari.

\section{Prosedur Pengujian di Laboratorium}

Setelah perlakuan selama 3 minggu, sampel PDKS dari masing-masing perlakuan dikeringkan dan dihaluskan, selanjutnya dilakukan analisis prokimat lengkap untuk menentukan kadar bahan kering, kadar protein kasar, kadar serat kasar, kadar lemak kasar, bahan ekstrak tanpa Nitrogen (BETN), dan abu.

\section{Analisa Data}

Data yang diperoleh dianalisis menggunakan analisis sidik ragam/analysis of variance (ANOVA). Apabila terdapat perbedaan antar perlakuan, dilakukan pengujian lebih lanjut dengan Uji Jarak Berganda Duncan (Duncan Multiple Range Test) (DMRT) (Steel dan Torrie, 1993). 


\section{HASIL DAN PEMBAHASAN}

\section{Kadar Bahan Kering}

Bahan kering merupakan salah satu hasil dari pembagian fraksi yang berasal dari bahan pakan setelah dikurangi kadar air atau bahan pakan yang sudah dipanaskan pada suhu 100$105^{\circ} \mathrm{C}$ sehingga tidak adalagi kandungan airnya (Soejono, 1991). Rerata kadar bakan kering hasil analisis sidik ragam dapat dilihat pada Gambar 1 sebagai berikut :

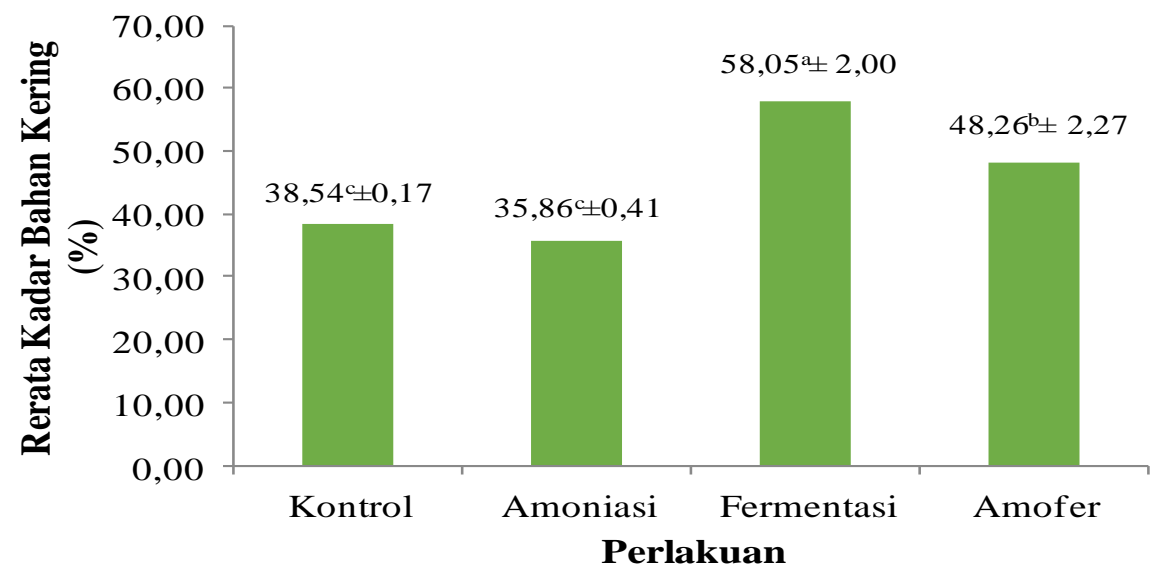

Gambar 1. Rerata Kadar Bahan Kering Pelepah Daun Kelapa Sawit

Terjadinya peningkatan kadar bahan kering pada perlakuan fermentasi dan amofer PDKS diduga disebabkan oleh aktivitas kapang Trichoderma viride selama fermentasi. Pada fermentasi jenis padat (12-60\% kadar air), kapang akan menyerap air dan nutrien selama proses pertumbuhannya, sehingga semakin lama fermentasi substrat semakin kering (Tayildizi et al., 2007).

Peningkatan kadar bahan kering akibat fermentasi menggunakan kapang Aspergillus niger juga dilaporkan oleh Nazaruddin (2013) pada substrat ampas sagu dan Wajizah et al. (2015) pada substrat pelepah sawit. Meskipun terjadi peningkatan, rerata kadar bahan kering pada perlakuan amofer masih lebih rendah dibandingkan perlakuan fermentasi. Penurunan ini diduga terjadi karena terlarutnya sebagian fraksi yang soluble akibat terjadinya reaksi kimia pada proses amoniasi dan terjadinya effluent lose pada metabolisme sel selama proses ensilase (Nurhaita dan Ruwendi, 2012).

Hal tersebut sesuai dengan pendapat Jackson (1977) yang melaporkan bahwa, penurunan persentase bahan kering PDKS disebabkan karena peningkatan level pemberian urea pada proses amoniasi, sehingga terjadi pelarutan dari beberapa nutrien yang terdapat pada PDKS yang merupakan bagian dari bahan kering seperti lignin, selulosa, hemiselulosa, silika. Selain itu, terjadinya pelarutan bahan - bahan organik akibat penambahan urea, penurunan bahan kering terjadi pada amoniasi PDKS juga disebabkan karena adanya penambahan air di dalam proses pelarutan urea (Hanafi, 2004 dan Imsya et al., 2005).

\section{Kadar Protein Kasar}

Dalam pakan ternak, protein kasar dihitung sebagai $\mathrm{N}$ dikali faktor 6,25, dengan asumsi bahwa protein dari pakan ternak umumnya mengandung rata-rata 16\% N (Imedpub.com., 2021). Pada kenyataannya, nitrogen yang terdapat di dalam bahan pakan tidak hanya berasal dari protein saja melainkan juga dapat berasal dari senyawa bukan protein atau non protein 
nitrogen (NPN). Dengan demikian maka nilai dari yang diperoleh dari perhitungan di atas merupakan nilai dari apa yang disebut protein kasar (Kamal, 1998). Rerata kadar protein kasar hasil analisis sidik ragam dapat dilihat pada Gambar 2 sebagai berikut :

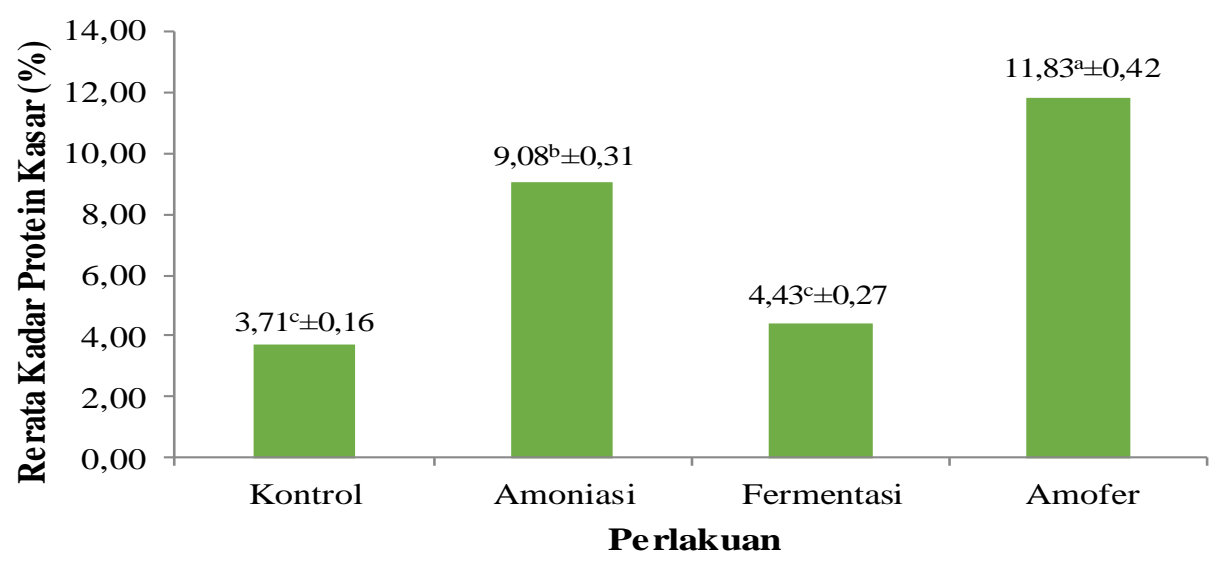

Gambar 2. Rerata Kadar Protein Kasar Pelepah Daun Kelapa Sawit

Tingginya kadar protein kasar pada perlakuan amoniasi dan amofer disebabkan karena adanya penambahan urea seperti yang dinyatakan oleh Jamarun dan Harnentis (1997), bahwa penggunaan urea dapat meningkatkan kandungan protein kasar bahan yang diamoniasi akibat terfiksasinya $\mathrm{N}$ yang berasal dari urea ke dalam jaringan bahan yang diamoniasi, sehingga akan meningkatkan kadar protein kasar yang terdapat pada bahan pakan. Ibrahim dan Schire (1985) menyatakan, tujuan utama penambahan urea pada proses amoniasi adalah sebagai upaya peningkatan kandungan $\mathrm{N}$ (protein kasar) serta daya cerna.

\section{Kadar Serat Kasar}

Penentuan serat kasar suatu bahan pakan pada analisis proksimat dilakukan secara gravimetri, dengan mengukur residu yang tidak larut dengan hidrolisis asam yang diikuti oleh hidrolisis basa (Feedipedia.org., 2021). Serat kasar bagi ternak ruminansia digunakan sebagai sumber energi utama yang berperan utama penting dalam metabolisme tubuh sehingga perlu diketahui kecernaanya dalam tubuh ternak. Rerata kadar serat kasar hasil analisis sidik ragam dapat dilihat pada Gambar 3 sebagai berikut :

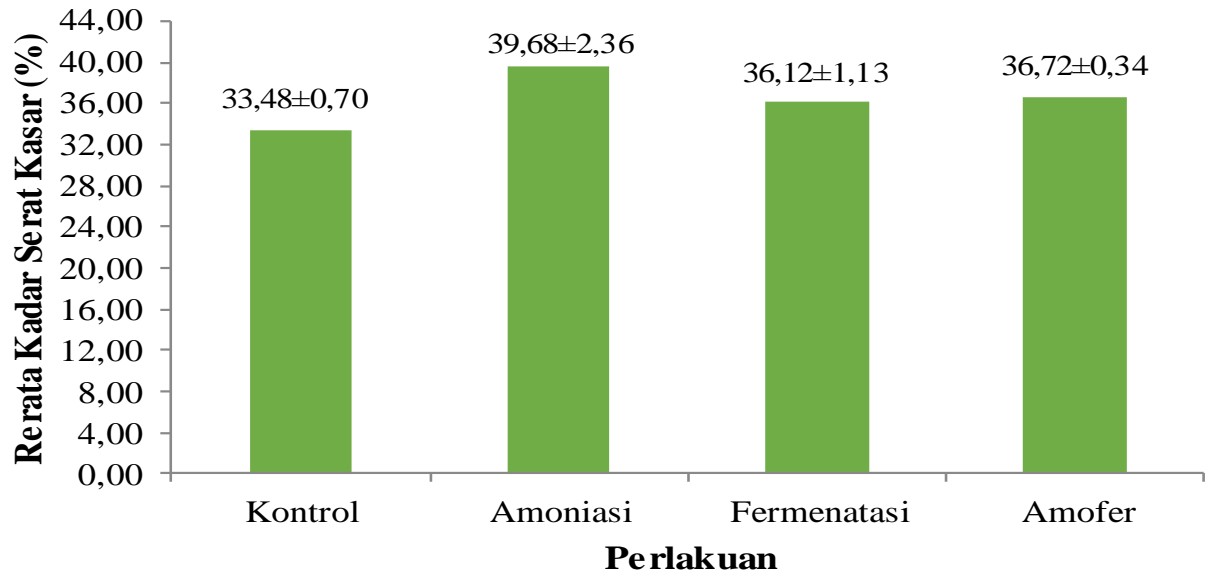

Gambar 3. Rerata Kadar Seray Kasar Pelepah Daun Kelapa Sawit 
Peningkatan serat kasar dapat juga disebabkan effluent loss yang melarutkan beberapa fraksi yang soluble akibat reaksi kimia yang terjadi selama proses amoniasi, sehingga proporsi serat kasar meningkat (Nurhaita dan Ruswendi, 2012). Proses amoniasi yang tidak optimal diduga menjadi penyebab sukarnya penetrasi enzim selulase oleh kapang $T$. viride karena struktur serat yang masih kompak, sehingga degradasi serat kasar tidak efektif. Hal tersebut diduga karena kadar air yang tidak optimal berakibat proses ureolysis berjalan lambat dan ammonia yang dibebaskan minimal, sehingga proses amoniasi terhambat (Marjuki, 2013).

\section{Kadar Lemak Kasar}

Lemak merupakan bagian dari lipida yang merupakan istilah umum yang meliputi sterol, lilin, lemak, fosfolipid dan sfingomielin. Lemak merupakan ester asam lemak dari gliserol, yang mempunyai dua peran utama, yaitu sebagai sumber energi dan sumber asam lemak esensial. Dalam kimia bahan pakan, kandungan lemak sering mengacu pada kandungan lemak kasar, yang berarti semua senyawa yang dapat larut dalam pelarut eter (FAO.org, 2021). Dalam makanan, komponen lemak memegang peranan penting yang menentukan karakteristik fisik keseluruhan, seperti aroma, tekstur, rasa serta tampilan (Hart, 2003). Rerata kadar lemak kasar hasil analisis sidik ragam dapat dilihat pada Gambar 4.

Semua perlakuan amoniasi, fermentasi serta amofer menghasilkan kadar lemak yang lebih tinggi dibanding kontrol, dengan persentase yang relatif sama. Sejalan dengan penelitian Tilawati (2016) yang menggunakan substrat limbah kulit kopi menunjukkan bahwa, terjadi peningkatan kadar lemak kasar pada perlakuan fermentasi menggunakan T. viride dan A. niger masing-masing sebesar $12 \%$ dan $25,3 \%$ dibanding perlakuan kontrol. Hal tersebut menunjukkan bahwa jamur $T$. viride dan A. niger mampu menghasilkan enzim lipase selama proses fermentasi berlangsung.

Rahman (2003) menyatakan bahwa kandungan lemak kasar dipengaruhi oleh laju pertumbuhan mikroba dan oleh konsetrasi substrat dalam medium selama fermentasi berlangsung. Peningkatan kandungan lemak kasar pada pelepah daun kelapa sawit yang difermentasi merupakan indikasi adanya sintesis asam lemak didalam pelepah daun kelapa sawit tersebut. Hasil uraian karbohidrat dalam proses fermentasi menghasilkan asam-asam lemak, sehingga kadar lemak dalam bahan pakan yang difermentasi mengalami peningkatan.

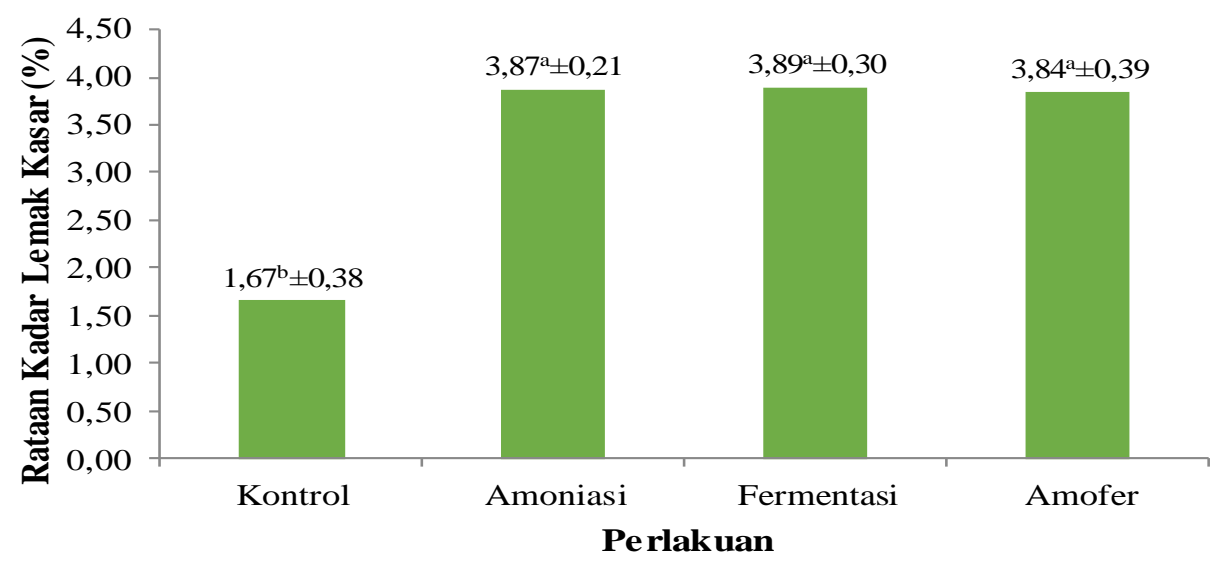

Gambar 4. Rerata kadar Lemak Kasar Pelepah Daun Kelapa Sawit

\section{Kadar Bahan Ekstrak Tanpa Nitrogen (BETN)}

Menurut Tillman et al. (1998) bahan ekstrak tanpa nitrogen BETN merupakan komponen dari karbohidrat yang berisi zat- zat monosakarida, disakarida, trisakarida, dan polisakarida terutama dari pati dan semua yang mudah larut dalam larutan asam dan basa. Rerata kadar 
bahan ekstrak tanpa nitrogen hasil analisis sidik ragam dapat dilihat pada Gambar 5 sebagai berikut :

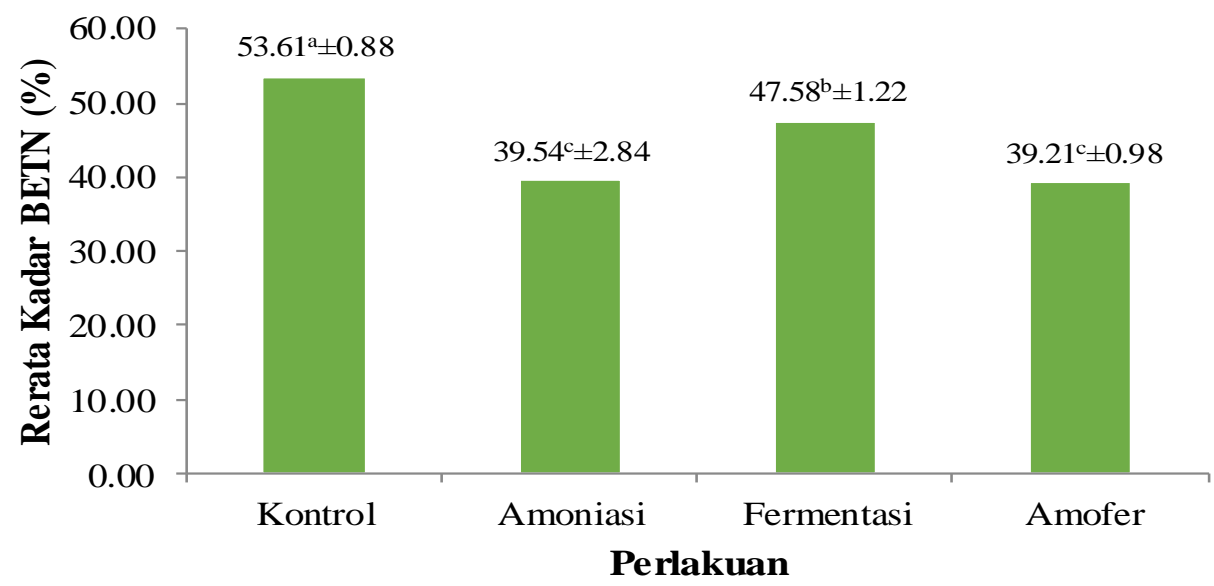

Gambar 5. Rerata Kadar Bahan Ekstrak Tanpa Nitrogen (BETN) Pelepah Daun Kelapa Sawit

Semua perlakuan menyebabkan turunnya kadar BETN dibandingkan kontrol, terutama pada perlakuan amoniasi dan amofer, sedangkan pada perlakuan fermentasi tingkat penurunan relatif lebih rendah. Hal ini diduga pada proses amoniasi dan amofer, urea yang bersifat higroskopis menyebabkan fraksi terlarut mengalami effluent loss, sehingga terjadi penurunan kadar BETN yang sangat besar (Nurhaita dan Ruswendi, 2012). Pada perlakuan fermentasi, diduga penurunan kadar BETN lebih disebabkan oleh mikroorganisme selama fermentasi berlangsung mencerna bahan yang mudah terdegradasi seperti karbohidrat, yang merupakan komponen utama dalam BETN sebagai sumber nutrisinya. Sejalan dengan pendaat Anwar (2008) yang menyatakan bahwa BETN tersebut digunakan sebagai energi oleh mikroba dalam pertumbuhannya. Mikroorganisme dapat mencerna bahan organik yang mudah terdegradasi seperti BETN.

\section{Kadar Abu}

Abu merupakan hasil pembakaran bahan kering dalam tanur dengan menggunakan suhu $550-600^{\circ} \mathrm{C}$. Kadar abu adalah salah satu komponen penyusun bahan kering. Menurut Sumardji et al. (1989), kandungan abu dan komposisinya tergantung pada macam bahan dan proses pengabuannya. Kadar abu menentukan kadar bahan organik dari suatu bahan pakan dan abu merupakan bahan yang bersifat anorganik pada bahan pakan. Rerata kadar abu hasil analisis sidik ragam dapat dilihat pada Gambar 6.

Peningkatan kadar abu bisa terjadi karena terjadi penurunan bahan organik selama proses fermentasi. Hal ini disebabkan adanya proses degradasi substrat oleh mikroorganisme. Semakin banyak bahan organik yang mengalami degredasi maka akan semakin banyak terjadinya peningkatan kadar abu secara proposional. Peningkatan kadar abu tidak diharapkan, karena semakin banyak meningkatnya kadar abu, maka akan semakin berkurang kandungan bahan organik yang terkandung di dalam substrat.

Peningkatan kadar abu bisa terjadi karena terjadi penurunan bahan organik selama proses fermentasi. Hal ini disebabkan adanya proses degradasi substrat oleh mikroorganisme. Penelitian Rizali et al. (2018) pada PDKS juga mendapatkan bahwa terjadi peningkatan kadar 
abu pada proses fermentasi, baik menggunakan $T$. viride maupun T. harzianum. Semakin banyak dosis inokulum yang diberikan dalam substrat, semakin tinggi kenaikan kadar abu yang dihasilkan.

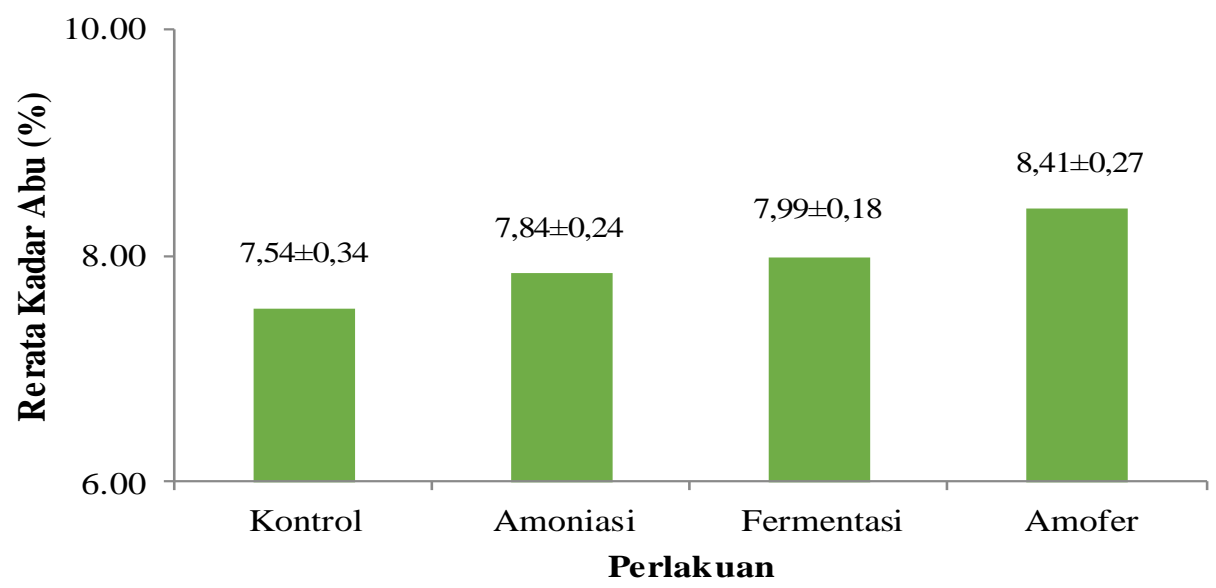

Gambar 6. Rerata Kadar Abu Pelepah Daun Kelapa Sawit

\section{KESIMPULAN DAN SARAN}

Secara keseluruhan, semua perlakuan belum mampu menurunkan kadar serat kasar dan tidak berpengaruh terhadap kadar abu substrat, namun meningkatkan kadar lemak kasar dibandingkan kontrol. Dibandingkan semua perlakuan, fermentasi menggunakan Trichoderma viride memberi hasil yang terbaik, karena dapat mempertahankan kadar bahan kering dan BETN tetap tinggi, serta cenderung meningkatkan kadar protein substrat. Untuk penelitian selanjutnya disarankan untuk melakukan amoniasi dan fermentasi dengan lama dan dosis penggunaan inokulum yang berbeda, agar diperoleh kondisi yang optimum untuk meningkatkan kualitas pelepah daun kelapa sawit (PDKS) sebagai pakan ternak ruminansia. Juga disarankan penelitian lebih lanjut mengenai uji kecernaan pada pelepah daun kelapa sawit amoniasi dan fermentasi baik secara in vitro serta in vivo.

\section{DAFTAR PUSTAKA}

Feedipedia.org. 2021. Crude Fiber. https://www.feedipedia.org/node/8330\# [Diakses 27 Januari 2021].

FAO.org. 2021. What is food composed of? http://www.fao.org/3/s4314e/s4314e04.htm. [Diakses 27 januari 2021].

Hanafi, N. D. 2004. Perlakuan Silase dan Amoniasi Daun Kelapa Sawit sebagai Bahan Baku Pakan Domba. Fakultas Pertanian - Program Studi Produksi Ternak. Universitas Sumatera Utara. Medan.

Hart, Harold . 2003. Kimia Organik: Suatu Kuliah Singkatan. Penerbit Erlangga. Jakarta. 
Hastuti, D., S. Nur A., dan B. Iskandar M. 2011. Pengaruh Perlakuan Teknologi Amofer (Amoniasi Fermentasi pada Limbah Tongkol Jagung sebagai Alternatif Pakan Berkualitas Ternak Ruminansia. Mediagro. Vol 7 (1) : 55-65.

Ibrahim, M. N dan M. Schire., J. B. 1985. Procedure in Treating Straw with Urea Proceeding. Protential of Rice Straw in Ruminant Feeding. Departement of Animal Scince. University of Perodeniya. Srilanka.

Imsya, A. dan R. Palupi. 2009. The Change of Lignin, NDF ( Neutral Detergent Fiber), dan ADF ( Acid Detergent Fiber) Palm Fronds With Biodegumming Process as Fiber source Feedstuff for Ruminansia. JITV 14 (4): 284-288.

Jackson, M. G. 1997. Rice Straw as Livestock Feed. In : The World Animal Nutrition. Selection Articles from The Animal. Review. Food Agriculcural Organization of The United Nation. Rome.

Jamarun, Novirman dan Harnentis. 1997. Penggunaan Bahan Kimia Unruk Meningkatkan Kualitas Jerami Padi. Jurnal Peternakan dan Lingkungan. Vol.3 No.2 (Juni).

Kamal, M. 1998. Nutrisi Ternak I. Rangkuman. Lab. Makanan Ternak Jurusan Nutrisi dan Makanan Ternak. Fakultas Peternakan. Universitas Gadjah Mada. Yogyakarta.

Nazaruddin, 2013. Peningkatan Nilai Nutrisi Ampas Sagu Melalui Fermentasi Menggunakan Aspergilus niger dengan Penambahan Sumber Karbohidrat Terlarut yang Berbeda. Skripsi. Jurusan Peternakan Fakultas Pertanian Universitas Syiah Kuala. Darussalam. Banda Aceh.

Nurhaita dan Ruswendi. 2012. Efek beberapa metoda pengolahan limbah dan kelapa sawit terhadap kandungan gizi dan kecernaan in vitro. Seminar Inovasi Teknologi Pertanian Spesifik Lokasi Mendukung Empat Sukses Kementrian Pertanian Prov. Bengkulu. Balitbang Pertanian Kementrian Pertanian.

Marjuki. 2013. Metode pemanfaatan limbah sebagai pakan. http://marjuki.lecture.ub.ac.id/files/2013/04/METODE-PEMANFAATAN-LIMBAHSEBAGAI-PAKAN.pdf [Diakses 27 Januari 2021]

Rahman. 2003. Teknologi Fermenatasi Industri. Penerbit Arcan. Jakarta.

Rizali, A. F., M., Hafiz, A. , dan Anis, W. 2018. Utilization of Waste of Midrid and Palm Oil Leaves Through Fermentation of Trichoderma sp. As Beef Catlle Feed. Universitas Lambung Mangkurat. Banjarmasin.

Sarwono, B., 1996. Beternak Ayam Buras. Penebar Swadaya. Jakarta.

Sumardji, S., B. Haryono dan Suhardi. 1989. Analisa Bahan Makanan dan Pertanian. Penerbit Liberty. Yogyakarta.

Soejono. M. 1991. Analisis dan Evaluasi Pakan. Petunjuk Laboratorium. Pusat Antar Universitas Bioteknologi. Fakultas Peternakan. Universitas Gadjah Mada. 
Steel, R. G. D. dan J. H. Torrie. 1993. Prinsip dan Prosedur Statistika (diterjemahkan dari : Principles and Procedures of Statistic, Penerjemah : B. Sumatri). PT. Gramedia. Jakarta. 748 halaman.

Tanyildizi, MS, Dursun O, Murat E. 2007. Production of Bacterial Amylase by B. Amylaloliquefaciens Under Solid Subrate Fermentation. Biochemical Engineering Jurnal. Vol. 37; 294-297.

Tilawati. 2016. Kandungan protein kasar, lemak kasar dan serat kasar limbah kulit kopi yang difermentasi menggunakan jamur Aspergiluus niger dan Trichoderma viride. https://core.ac.uk/download/pdf/77626265.pdf. [Diakses 20 Desember 2020]

Tillman, A. D., Hartadi, H., Reksohadiprojo S., Prawirokusumo S., dan Lebdosoekojo S. 1998. Ilmu Makanan Ternak Dasar. Gadjah Mada University Press. Yogyakarta.

Wahyono, D.E., Hardianto, R., Anam, C., Wijono, D.B., Purwanto, T. dan Malik, M., 2003. Strategi Pemanfaatan Limbah Pertanian dan Agroindustri Untuk Pembuatan Pakan Lengkap Ruminansia. Makalah Seminar Nasional Pengembangan Sapi Potong, Lembang, Jawa Barat. Pusat Penelitian dan Pengembangan Peternakan, Badan Litbang Pertanian, Bogor.

Wazijah , S., Samadi., Usman, Y., Mariana, E., 2015. Evaluasi Nilai Nutrisi dan Kecernaan In Vitro Pelepah Kelapa Sawit (Oil Palm Fronds) yang Difermentasi Menggunakan Aspergilus niger dengan Menambahakan Sumber Karbohidrat yang Berbeda. Agripet. 15(1): 13-19. 